\title{
Imaginarios técnicos en el Obelisco. Representaciones culturales de modernización en Buenos Aires de la década de 1930.
}

Nicolás Barboza Dri

FADU-UNL

\section{Resumen}

El proyecto y construcción del Obelisco en el año 1936 no estuvo exento de debates. La discusión disciplinar, polarizada entre los defensores de la tradición académica y los de una modernidad anclada principalmente en la valorización técnica desde su constitución formal y material, promueve un estimulante diálogo. Las transformaciones políticas y económicas de la década de I930 en Argentina van de la mano del impulso para una modernización del país, tanto en el plano social como en términos espaciales y territoriales. En esta escena, la trascendencia del Obelisco radica principalmente en las representaciones e imaginarios que puede ser analizado a partir de las revistas disciplinares del período y las producciones fotográficas con las que Horacio Coppola reproduce la Buenos Aires de aquella década. Analizar las discusiones disciplinares en sede cultural que se produjeron alrededor del monumento permite comprender
Palabras clave:

Obelisco, configuración urbana, modernización, técnica, debate. 
una nueva realidad social anclada en el progreso de la modernización.

\section{Abstract \\ Technical Imaginaries in the Obelisk. Cultural Representations of the Modernization of Buenos Aires in the 1930's}

The project and the construction of the Obelisk in the year 1936 was not exempt from debate. The disciplinary discussion -between the defenders of the academic tradition, and the exponents of a modernity that centers Keywords:

Obelisk, urban configuration, modernization, technique, debate.

around the technical valorization from its formal and material constitution - fosters a stimulating dialogue. The political and economic transformations in the I930s in Argentina go hand in hand with the impulse for a modernization in social, spatial and territorial terms. In this context, the importance of the Obelisk lies in the representations and imaginaries that can be analyzed by studying the disciplinary magazines of the period, as well as the reproductions of the 1930s Buenos Aires in Horacio Coppola's photographs. Analyzing the disciplinary discussions in cultural base that took place around the monument, allows us to understand a new social reality anchored in the progress of modernization.

El impulso que la obra pública adquirió en Argentina de la década de I930, particularmente en su capital Buenos Aires, se reviste de múltiples condiciones coyunturales propias de los procesos históricos, muy importantes para su análisis. Estudiar el Obelisco, en tanto obra de arquitectura como producción cultural, es de interés por cuanto constituye un testimonio físico de la sociedad que la produjo, una permanencia material significativa, cuya mirada permite una reconstrucción de los valores y significados culturales de la época.

La situación de Buenos Aires en la década de 1930, marcada principalmente por las obras de la política estatal, se encuentra en desarrollo de un intento 